\title{
研究速報
}

\section{分子遺伝マーカーからマルハナバチ集団のコロニー密度を 推定するための新規な方法}

\section{A Novel Method for Estimating Nest Density in Bumblebee Populations from Molecular Genetic Markers}

\author{
野村哲郎 \\ Tetsuro Nomura \\ 京都産業大学総合生命科学部生命資源環境学科 \\ Department of Bioresources and Environmental Sciences, \\ Faculty of Life Sciences, Kyoto Sangyo University \\ e-mail:nomurat@cc.kyoto-su.ac.jp

\begin{abstract}
Bumblebees (Bombus spp.) are important pollinators of both wildflowers and crops. In recent year, declines of population size have been reported in many Bumblebee species in various countries. In order to design effective conservation plans, nest (colony) density in a habitat is an essentially important information. In the present study, a novel method for estimating nest density using molecular genetic markers was proposed, by extending the concept of neighborhood size in population genetics. The proposed method was compared with the conventional method used in previous studies by applying to microsatellite data of Bombus hypocrite sapporoensis. Based on the obtained estimates of nest density, advantage and disadvantage of the two methods were discussed. An interpretation of estimate obtained by the proposed method was also presented from a viewpoint of conservation genetics.
\end{abstract}

Key words: Bumblebees, Nest density, Molecular genetic markers, Conservation, Neighborhood size.

\section{1.はじめに}

マルハナバチ類 (Bombus spp.) は, 主に北半球に約 250 種が分布し (Goulson, 2010), 多くの顕 花植物の花粉媒介昆虫として生態系の中で重要な位置を占めている(熟谷, 1998)。また，マルハ ナバチ類はトマトなどのハウス栽培で授粉昆虫として利用されるほか，野外の農産物の受粉にも 重要な役割を果たしている (Goulson, 2010)。近年，世界各国で在来マルハナバチの減少が報告さ れており，その減少や絶滅が生態系や農産物の生産に多大な影響を及ぼすことが懸念されている (Williams and Osborne, 2009; Goulson, 2010; Cameron et al., 2011).

マルハナバチ類の保全に向けた基礎情報を得る目的で，各地のマルハナバチ相を明らかにする 
調査が行われてきた (中谷, 1999; 井上ら, 2007; 高橋ら, 2010; 工藤・井本, 2012). これらの調査 は目撃・採集された個体数に基づくものであるが, 真社会性昆虫のマルハナバチ類では野外で観 察される個体の大半は, 生殖に直接かかわることのないワーカー(働き蜂)である. したがって, 生息地で目撃・採集された個体数から，近交係数の上昇や遺伝的浮動に伴う遺伝的多様性の低下 など集団を構成する生殖個体の数の有限性によって生じる遺伝現象を評価することはできない. これらの遺伝現象を規定する集団の有効な大きさ (effective population size) は, 保全遺伝学にお いて最も重要なパラメータの 1 つである (Frankham et al., 2010). マルハナバチ類のような半 倍数性生物の集団の有効な大きさ $\left(N_{e}\right)$ は, 女王の数を $N_{f}$ として単婚 (monogamy) を仮定すれば $N_{e}=1.5 N_{f}$ である (Ellis et al., 2006; Charman et al., 2010; Nomura and Takahashi, 2012). マ ルハナバチでは 1 つのコロニー(巣)を 1 匹の女王が創設するので, コロニー数が推定できれば, その 1.5 倍として集団の有効な大きさが推定できる.

生息域の広範囲にコロニーが形成されるマルハナバチ類では, マイクロサテライトなどの分子遺 伝マーカーを用いて生息域におけるコロニーの密度としてコロニー数が推定されてきた. その推定 法は, Darvill et al. (2004) によって開発され, その後, Kinight et al. (2005, 2009), Nagamitsu and Yamagishi (2009) などの研究に適用されてきた.この方法では, 採饂探索域の面積の推定, 採饂探索域内のコロニー数の推定を行い，2つの推定值からコロニー密度が求められる. したがつ て, 得られたコロニー密度の信頼性は, 採餌探索域の面積および採餌探索域内のコロニー数の推 定精度に依存している.

本研究では, 従来の推定法とは異なる発想によって, 採䶿探索域の面積や採餌探索域内の個体 数を直接に推定することなくコロニー密度を推定する方法を提示する. また, 提示した方法と従 来の方法をマルハナバチのマイクロサテライトデータに適用し, 両者から推定されたコロニー密 度を比較するとともに，2つの方法の利点と欠点について議論する. さらに, 提示した方法から 得られた結果の保全遺伝学的解釈についても考察する.

\section{2. 方 法}

平面上に連続分布した生物においては，生息地の分断や孤立がなくても，配偶子の拡散距離の 制限によって遠く離れた個体間には遺伝的分化，すなわち距離による隔離 (isolation by distance) が生じる. Wright $(1946,1969)$ は近傍の大きさ (size of neighborhood) と呼ばれる概念を導入し て, 距離による隔離を理論的に解析した. 近傍の大きさとは, 連続分布する生物において両親が 無作為に取り出されたとみなされる仮想的分集団の大きさである. 本研究で提示する方法は, 近 傍の大きさの概念を応用したものである.

著者が調査の対象としている北海道の原野のように営巣可能な場所が連続した広大な土地に広 がり, その中にコロニーは一様に分布するものとする. このような調査地において, 1 か所の採 集地点を定めて，そこに飛来する多数のマルハナバチを採集する場面を想定する. 実際の採集は, 定められた採集地点を中心として, 数 $\mathrm{m}$ から数 $10 \mathrm{~m}$ の範囲内で行われるが, すべての個体の採 集地点を定められた 1 点で近似する.

各コロニーから飛び立つた個体は，花粉や花蜜を求めてランダムな方向へ採饂探索することを 
仮定する. ミツバチはコロニー内でのダンスによるコミュケーションによって，花資源の方向と コロニーからの距離を他個体に伝える習性を持つが, マルハナバチはこのようなコミュケーショ ンは行わず，同一コロニー内の各個体は独自に得た情報に基づいて，独立に採餌探索行動をする ことが知られている (Goulson, 2010)。したがって，花資源が調査地内に豊富にあれば，個体がコ ロニーからランダムな方向に採饂探索をすると仮定することは妥当であると考えられる. また, Darvill et al. (2004) と同様に，すべてのコロニーについて個体の採餌探索距離は同一の確率分布 にしたがうものとする.

\section{1 コロニーの密度の推定法}

以下に示す推定法の導出は，集団遺伝学における近傍の大きさの理論 (Wright, 1969, p. 302-303; 木村, 1960. p. 235-236)を応用したものである.

図 1 に，仮定したモデルの概略を示した. $x-y$ 座標からなる平面を考えて，採集地点を原点 $(0,0)$ とする. 地点 $(\mathrm{x}, \mathrm{y})$ にあるコロニーから, マルハナバチが原点に飛来する確率密度 $z$ は, $x$ と $y$ に相関がなく, 平均と分散がともに 0 および $\sigma^{2}$ の原点を中心とした 2 変量正規分布の密度関数

$$
z=\frac{1}{2 \pi \sigma^{2}} \exp \left(\frac{-\left(x^{2}+y^{2}\right)}{2 \sigma^{2}}\right)
$$

により与えられるものとする.

$n$ を一辺が $2 \sigma$ の正方形の中に存在するコロニーの数とすれば，コロニーの密度は

$$
d=\frac{n}{4 \sigma^{2}}
$$

である(図 1)。したがって,

$$
\frac{1}{d}=\frac{4 \sigma^{2}}{n}
$$

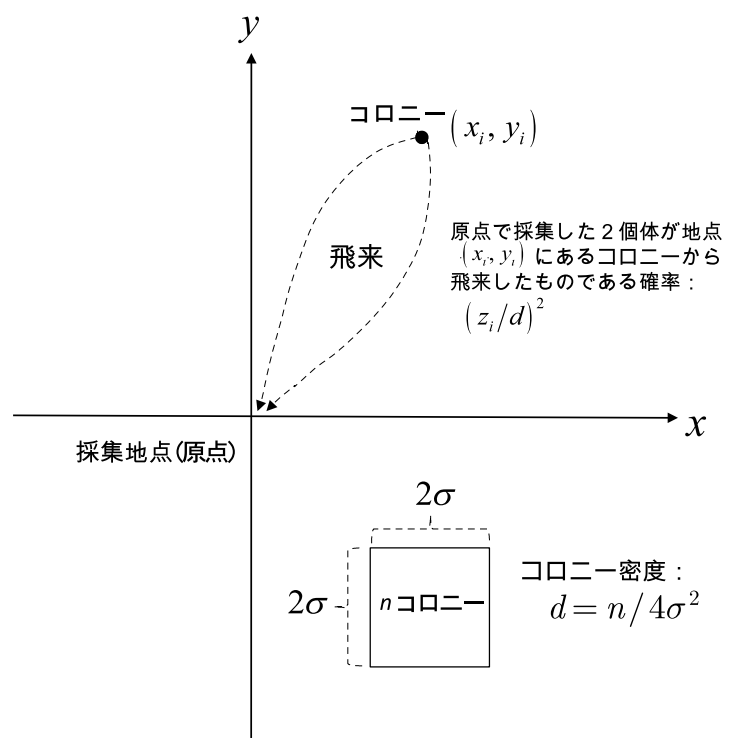

図 1. 本研究で仮定したモデルの概念図. 


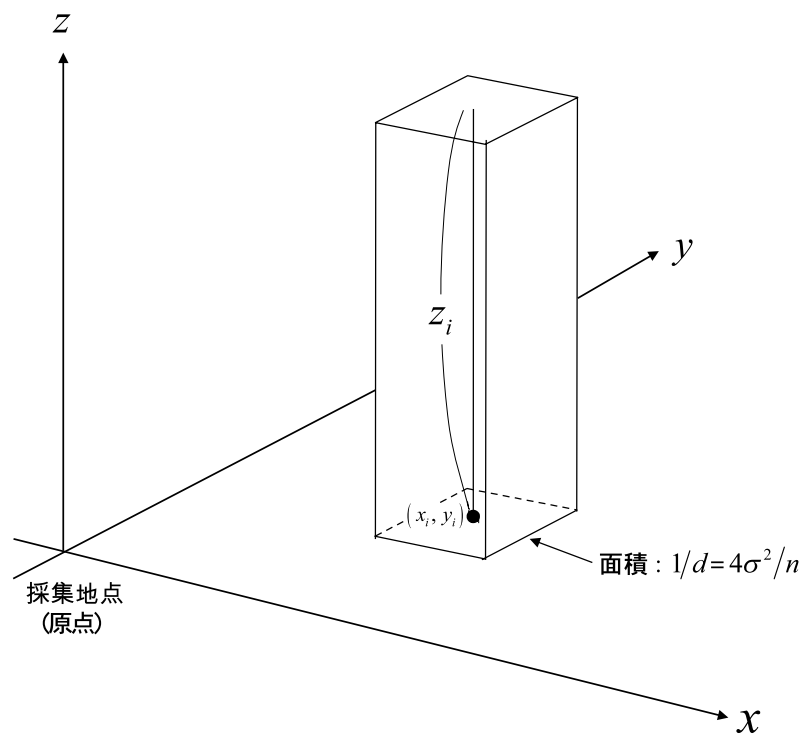

図 2. 地点 $\left(x_{i}, y_{i}\right)$ にあるコロニーから採集地への個体の飛来確率 を求めるための説明図.

の面積を持つ区画内に平均して 1 つのコロニーが存在することになる. 地点 $\left(x_{i}, y_{i}\right)$ にあるコロ ニーを考えて, 式 $(1)$ に $\left(x_{i}, y_{i}\right)$ を代入して得られる確率密度を $z_{i}$ とすると, 採集地点(原点)に 飛来したマルハナバチが地点 $\left(x_{i}, y_{i}\right)$ にあるコロニーから飛来した確率は, 図 2 に示した立方体の 体積すなわち $z_{i} / d$ である (補足説明は付録を参照).

$Q$ を原点で採集した 2 個体のマルハナバチが同一のコロニーから飛来した確率とすれば,

$$
Q=\sum_{-\infty}^{\infty}\left(\frac{z_{i}}{d}\right)^{2}=\frac{1}{d} \sum_{-\infty}^{\infty} \frac{z_{i}^{2}}{d}
$$

である.ここで, $\sum_{-\infty}^{+\infty}$ は平面全域の全コロニーにわたる和を示す，積分で表せば $Q$ は

$$
Q=\frac{1}{d} \int_{-\infty}^{\infty} \int_{-\infty}^{\infty} \frac{1}{4 \pi^{2} \sigma^{4}} \exp \left(\frac{-\left(x^{2}+y^{2}\right)}{\sigma^{2}}\right) d x d y
$$

と書ける. さらに, 上の式の被積分関数は

$$
\frac{1}{4 \pi^{2} \sigma^{4}} \exp \left(\frac{-\left(x^{2}+y^{2}\right)}{\sigma^{2}}\right)=\frac{1}{4 \pi \sigma^{2}}\left[\frac{1}{2 \pi(\sigma / \sqrt{2})^{2}} \exp \left(\frac{-\left(x^{2}+y^{2}\right)}{2(\sigma / \sqrt{2})^{2}}\right)\right]
$$

と書け, 右辺の [ ] 内が 2 変量正規分布の密度関数であることに注意すれば

$$
Q=\frac{1}{d} \cdot \frac{1}{4 \pi \sigma^{2}}
$$

を得る.

以上より, コロニー密度 $d$ は

$$
d=\frac{1}{4 \pi \sigma^{2} Q}
$$


によって得られる.

\section{$2.2 Q$ の推定法}

式 (2) を用いてコロニー密度を推定するには， $Q$ と $\sigma^{2}$ を推定する必要がある. まず， $Q$ の推定 について考える. マルハナバチは，単婚の繁殖システムを持つ(Crozier and Pamilo, 1996). した がつて，採集個体についてマイクロサテライトなどの分子遺伝マーカーのデータが利用できる場 合には，個体間のきょうだい関係を推定 (sibship reconstruction)できれば, きょうだいと判定さ れた 2 個体は同一コロニーから飛来した個体とみなすことができる. DNA マーカーから sibship reconstruction を行うためのプログラムは, いくつかのものが公開されているが, 最近の研究で は Colony 2.0（Wang, 2004)が用いられることが多い.

ある採集地点で得られた $N$ 個体について sibship reconstruction を行つたところ， $n$ ペアのきょ うだいが検出されたとすれば， $Q$ は

$$
Q=\frac{n}{N(N-1) / 2}
$$

として推定できる.

\section{$2.3 \sigma^{2}$ の推定}

採集地点(原点)で採集された個体が地点 $(x, y)$ にあるコロニーから飛来したなら, その個体の採 餌探索距離 $\left(r\right.$ : forage distance) は $r^{2}=x^{2}+y^{2}$ である. したがって，地点 $(x, y)$ にあるコロニー から，マルハナバチが原点に飛来する確率密度は,

$$
\frac{1}{2 \pi \sigma^{2}} \exp \left(-\frac{r^{2}}{2 \sigma^{2}}\right)
$$

と表すことができる．原点に採餌探索距離 $r$ で飛来する個体が属するコロニーは，原点を中心と した半径 $r$ の円周上にあるので, 採集された個体が採餌探索距離 $r$ を持つ確率 $(\mathrm{P}(r): r$ の密度関 数) は, 上記の確率密度に半径 $r$ の円周長 $2 \pi r$ を乗じて得られる. すなわち

$$
P(r)=\frac{r}{\sigma^{2}} \exp \left(-\frac{r^{2}}{2 \sigma^{2}}\right)
$$

である.

式 (3)より, 採䬧探索距離の平均值 $\left(\mu_{r}\right)$ は,

$$
\mu_{r}=\int_{0}^{\infty} r P(r) d r=\sqrt{\frac{\pi \sigma^{2}}{2}}
$$

であるから,フィールド調査によって採餌探索距離 $r$ の平均值が得られれば,

$$
\sigma^{2}=\frac{2 \mu_{r}^{2}}{\pi}
$$

として $\sigma^{2}$ が推定できる. また, 密度関数 (3) は,

$$
\frac{d}{d r} P(r)=\frac{1}{\sigma^{2}} \exp \left(-\frac{r^{2}}{2 \sigma^{2}}\right)\left(1-\frac{r^{2}}{\sigma^{2}}\right)=0
$$

より, $r=\sigma$ で最大值をとる. したがって, 採餌探索距離 $r$ の分布を推定できれば, 採餌探索個 体数の最頻值(モード)を与える $r$ から $\sigma^{2}=r^{2}$ として推定值を得ることもできる.

図 3 は, 最頻值を $0.2,0.4$ および $0.8 \mathrm{~km}$ としたときの採餌探索距離の分布を式 (3) を用いて描 Jpn J Biomet Vol. 39, No. 1, 2018 


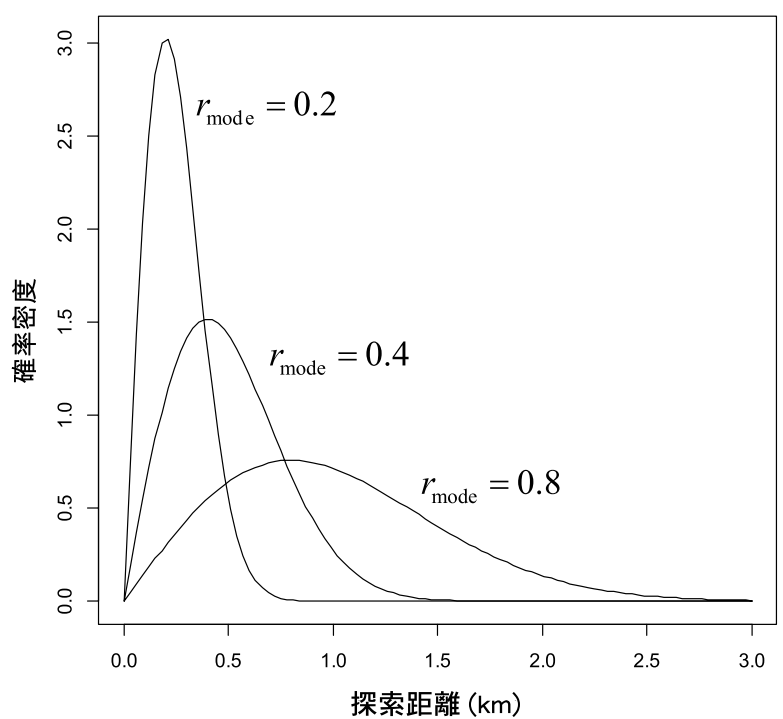

図 3. 採餌探索距離の最頻值 $\left(r_{\text {mode }}\right)$ を $0.2,0.4$ および 0.8 とした ときの式 (3) から求めた採餌探索距離の分布.

いたものである. Goulson (2010) によれば, マルハナバチ類の多くの種ではコロニーに近接した 植物に訪花することは少なく，コロニーからある程度，距離を隔てた場所にある植物を訪花する 習性がある，このような習性には，同一コロニー内のワーカー間での訪花植物をめぐる競合を回 避するため，あるいは鳥などの天敵にコロニーの場所を察知されることを回避するためなどの目 的があると考えられている (Goulson, 2010). いずれにしても, 図 3 は, 式 (3) が上記の習性から 期待される採餌探索距離の分布の特徵を描写できることを示している.

Wolf and Moritz (2008) は，セイヨウオオマルハナバチ(Bombus terrestris)のコロニーを野外 の一箇所に置き, そこを始点として直線上に $100 \mathrm{~m}$ から $1600 \mathrm{~m}$ まで $100 \mathrm{~m}$ 間隔で調査地点を設 けたトランセクト調査を行い，採䬧探索距離ごとに飛来した個体数を調べた．その結果，採飳探 索距離の平均值は $267.2 \mathrm{~m}$, 最頻值は $100 \mathrm{~m}$ であった. したがって, 平均值および最頻值に基づ く $\sigma^{2}$ の推定值 $\left(\mathrm{km}^{2}\right)$ は，それぞれ 0.045 および 0.01 となる.

Wolf and Moritz (2008) のフィールド実験は，採餌探索距離の分布を推定することを目的として 設計されたものである．その他にも，マーキングや小型レーダーを個体に装着して追跡調査をする 方法が用いられることもあるが (Goulson, 2010), それらの実施には多大な労力を要する. 実際に, コロニー密度を推定するときには，以下のようにして遺伝マーカーを用いて採餌探索距離の最大 值 (maximum forage distance: $r_{\max }$ ) の下限推定值 (minimum estimate)が用いられることが多い. まず，地点間の距離が測定されている複数の採集地のそれぞれから数十個体を採集し，マーカー 遺伝子座のタイピングを行う。つぎに, 得られた遺伝子型データを用いて sibship reconstruction を行い，sibすなわち同一コロニーから飛来した個体を共有する 2 つの採集地間の距離が最大のも のを選ぶ.これら 2 つの採集地間の距離を $R$ とすると， $r_{\max }$ の下限推定值は，これら 2 つの採 
集地を結ぶ線分の中点, すなわち $r_{\max }=R / 2$ として得られる.

このようにして推定された $r_{\max }$ は当然のことながら，限界採餌探索距離を表しているものでは ない. 実際の調査では推定された $r_{\max }$ を超える採飳探索距離で移動した個体もかなりの割合で採 集されることが予想される. いま，採集地を原点として半径 $r_{\max }$ 内にあるコロニーから採集地に 飛来する個体の割合を $\alpha$ とする. 式 (3) を仮定すれば,

$$
P\left(r<r_{\max }\right)=\int_{0}^{r_{\max }} P(r) d r=1-\exp \left(-\frac{r_{\max }^{2}}{2 \sigma^{2}}\right)=\alpha
$$

であるから，

$$
\sigma^{2}=-\frac{r_{\max }^{2}}{2 \ln (1-\alpha)}
$$

として, 推定された $r_{\max }$ と設定した $\alpha$ から $\sigma^{2}$ が推定できる.

上記の $r_{\max }$ の推定方法から考えると, $\alpha$ は $0.7 \sim 0.9$ 前後の值をとるものと推察される. その 場合, 式 (4)より $\sigma^{2}$ は $r_{\max }^{2}$ の $20 \sim 40 \%$ となる.

\section{3. 適用例}

\section{1 材料}

材料は，北海道産のマルハナバチの遺伝的多様性と集団構造の解明を目的とした研究の一環 として 2014 年 8 月 25 日に筆者が北海道中川郡音威子府村で採集したエゾオオマルハナバチ $(B$. hypocrite sapporoensis)のワーカー 31 個体である. 採集地はソバ畑と牧草地からなる農用地であ り，採集時にはソバ(Fagopyrum esculentum)やレッドクローバー(Trifolium pretense)などの訪 花植物が豊富にあり，エゾトラマルハナバチ(B. diversus tersatus), エゾナガマルハナバチ $(B$. yezoensis)のワーカーも飛来していたが，エゾオオマルハナバチのワーカーが優占していた．採 集は, ソバ畑の一角 $\left(44^{\circ} 44^{\prime} 3^{\prime \prime} \mathrm{N}, 142^{\circ} 15^{\prime} 45^{\prime \prime} \mathrm{E}\right.$, 半径約 $\left.10 \mathrm{~m}\right)$ で 90 分間程度行った.

採集した個体は, 共同研究者により 6 座のマイクロサテライトについてタイピングされた. 分 析および解析結果の詳細は, 高橋 (2016) に記載されている.

\section{2 開発した方法によるコロニー密度の推定}

マイクロサテライトデータに対して, Colony 2.0 (Wang, 2004) を用いて sibship reconstruction を行ったところ, 4 ペアの sibが検出された. したがって, 式 (2)の $Q$ は $Q=4 /\{31(31-1 / 2)\}=$ $8.602 \times 10^{-3}$ として推定される. エゾオオマルハナバチのワーカーの採餌探索距離に関する情報 は得られていないが, 近縁のセイヨウオオマルハナバチについては $r_{\max }=0.7 \mathrm{~km}$ 前後の值が推 定されている (Knight et al., 2005; Nagamitsu and Yamagishi, 2009). そこで $r_{\max }=0.7 \mathrm{~km}$ とし $\alpha=0.7$ を仮定すると, 式 (4)より $\sigma^{2}$ は

$$
\sigma^{2}=-\frac{0.7^{2}}{2 \ln (1-0.7)}=0.2035
$$

と推定される.これらを式 (1) に代入すると, コロニー密度の推定值は

$$
d=\frac{1}{4 \pi \times 0.2035 \times 8.602 \times 10^{-3}}=45.5\left(\mathrm{~km}^{-2}\right)
$$

となる. $\alpha=0.8$ および 0.9 としたときの結果は, 表 1 に示すとおりである.

Jpn J Biomet Vol. 39, No. 1, 2018 


\section{3 従来の方法によるコロニー密度の推定}

遺伝マーカーを用いたマルハナバチのコロニー密度の推定法は, Darvill et al. (2004) によって 開発された. その後, この方法は Kinight et al. (2005, 2009), Nagamitsu and Yamagishi (2009) などの研究に適用されてきた.この方法では, 以下の流れでコロニー密度が推定される.

\subsection{1 ステップ 1：採䭒探索距離の最大值および採餌探索域の面積の推定}

複数の調查地点を設け, 先に述べた方法で採餌探索距離の最大值の下限推定值 $\left(r_{\max }\right)$ を得る. 採餌探索域の面積は採集始点を中心とする半径 $r_{\max }$ の円内, すなわち

$$
A_{1}=\pi r_{\max }^{2}
$$

とする場合と, 半径 $2 r_{\max }$ の円内, すなわち

$$
A_{2}=\pi\left(2 r_{\max }\right)^{2}
$$

とする場合がある(これらの定義の妥当性については, 後ほど議論する). エゾオオマルハナバチ の例では採餌探索域の面積は

$$
\begin{aligned}
& A_{1}=\pi \times 0.7^{2}=1.539 \mathrm{~km}^{2} \\
& A_{2}=\pi \times(2 \times 0.7)^{2}=6.158 \mathrm{~km}^{2}
\end{aligned}
$$

となる.

\subsection{2 ステップ 2：採饁探索域内のコロニー数の推定}

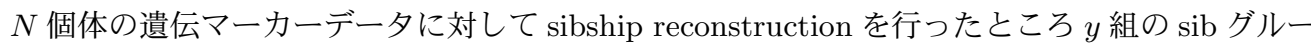
プが検出されたものとする．これらの sib グループは， 2 個体 (1ペア), 3 個体, $\cdots, m$ 個体 からな るグループに分けられる. 2 個体からなる sib グループの数を $n_{2}, 3$ 個体からなる sib グループ の数を $n_{3}$ などとするとすると, $y=\sum_{x=2}^{m} n_{x}$ である. $\operatorname{sib}$ が検出されなかった個体の数を $n_{1}$ と すると, $N=\sum_{x=1}^{m} x n_{x}$ である. また, $\sum_{x=1}^{m} n_{x}$ は採集された $N$ 個体が属するコロニーの数で あるが，採餌探索域内には採集個体が属さないコロニー，すなわち個体が採集されなかったコロ ニーが存在する．個体が採集されなかつたコロニーの数を $n_{0}$ とすれば，採餌探索域内の全コロ ニー数 $\left(N_{c}\right)$ は, $N_{c}=\sum_{x=0}^{m} n_{x}$ である. Nagamitsu and Yamagishi (2009) にしたがえば, $n_{0}$ は 次のようにして推定できる.

コロニー当たりの採集個体数 $n_{x}(x=1,2, \cdots, m)$ はポアソン分布にしたがうとし, 個体が採集 されなかったコロニー(その数は $n_{0}$ ) は観測值が得られなかったものと仮定する. この仮定の下で は，コロニー当たり $x=0,1,2, \cdots, m$ が採集される確率は

$$
P(x, \lambda)=\frac{e^{-\lambda} \lambda^{x}}{x !}
$$

で与えられる.ここで， $\lambda$ はコロニー当たりに採集される個体数の採餌探索域内の全コロニーに わたる平均值である.コロニーから 1 個体以上が採集される確率を用いて，採集された個体群を 生じる尤度 $(L(\lambda))$ を定義すると

$$
L(\lambda)=\prod_{x=1}^{m}\left\{\frac{e^{-\lambda} \lambda^{x}}{x !} /\left(1-\frac{e^{-\lambda} \lambda^{0}}{0 !}\right)\right\}^{n_{x}}
$$


である. $\lambda$ の最尤推定值は $L(\lambda)$ を最大にする $\lambda$ として得られる. $\lambda$ の最尤推定值を用いて採餌探 索域内の全コロニー数が

$$
N_{c}=\sum_{x=1}^{m} n_{x} /\left(1-\frac{e^{-\lambda} \lambda^{0}}{0 !}\right)
$$

として推定できる.

エゾオオマルハナバチの例では, R(R Development Core Team, 2016)の optimize 関数を用い れば $\lambda$ の最尤推定值は $\lambda=0.283$ であり，採餌探索域内の全コロニー数の推定值が $N_{c}=109.5$ と して得られる. $n_{0}=N_{c}-\left(n_{1}+n_{2}\right)=82.5$ であるから，採餌探索域内の 82.5 コロニーからは個 体が採集されなかったことになる.

\subsection{3 ステップ 3 : コロニー密度の推定}

コロニー密度は

$$
d_{1}=\frac{N_{c}}{A_{1}} \quad \text { あるいは } \quad d_{2}=\frac{N_{c}}{A_{2}}
$$

として推定される. エゾオオマルハナバチの例では

$$
\begin{aligned}
& d_{1}=71.2\left(\mathrm{~km}^{-2}\right) \\
& d_{2}=17.8\left(\mathrm{~km}^{-2}\right)
\end{aligned}
$$

\begin{tabular}{|c|c|c|c|c|}
\hline \multicolumn{3}{|c|}{ 提示した方法 } & \multicolumn{2}{|c|}{ 従来の方法 } \\
\hline$\alpha=0.7$ & 0.8 & 0.9 & $A_{1}=\pi r_{\max }^{2}$ & $A_{2}=\pi\left(2 r_{\max }^{2}\right)$ \\
\hline 45.5 & 60.8 & 86.9 & 71.2 & 17.8 \\
\hline
\end{tabular}

である. 適用例の結果を表 1 にまとめておく.

表 1. 提示した方法と従来の方法によるエゾオオマルハナバチのコロニー密度の推定値

$\alpha$ : 推定された最大採餌探索距離 $r_{\text {max }}$ を半径とする採集地を中心とした円内にあるコロ 二ーから採集地に飛来する個体の割合

従来の方法：Darvill et al. (2004) の方法

\section{4. 考 察}

従来のコロニー密度の推定法は, 採餌探索域の面積と採餌探索域内のコロニー数を推定して密 度を求める直接的な方法である，この方法では，採餌探索域の面積の定義によって密度の推定値 に大きな違いが生じる．採餌探索域の半径を $r_{\max }$ の 2 倍とするのは, Knight et al. (2009) によ れば以下の理由による. 図 4 に示すように, 採集地(原点)で採集されたワーカーは半径 $r_{\max }$ の 円内にあるコロニーから飛来した個体である，しかし，各コロニーは原点とは反対方向にもワー カーを送り出しているはずである. したがって，採集されたワーカーの姉妹ワーカーの採餌探索 域も考慮すると, 半径 $r_{\text {max }}$ の円内にある全コロニーの利用可能な総採餌探索域は半径 $2 r_{\max }$ の 円内として定義される.

しかしながら，この定義にしたがえば採集地にワーカーを送り込まない地点(たとえば，図 4 の X)にあるコロニーも定義された採饂探索域に含まれる．しかも，そのようなコロニーを含む面積 Jpn J Biomet Vol. 39, No. 1, 2018 


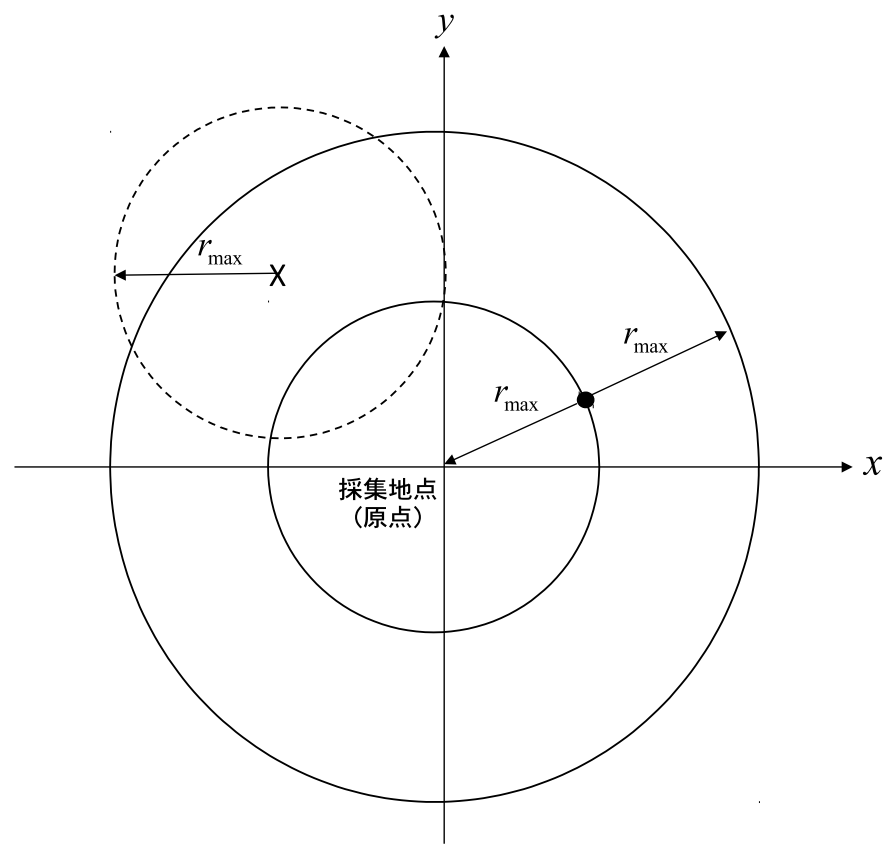

図 4. 最大探索距離 $\left(r_{\max }\right)$ と採餌探索域の関係を示す模式図.

○：半径が最大採餌探索距離 $r_{\max }$ を半径とする採集地を中心とした円上にあるコロニー $\mathrm{X}$ ：最大採餌探索域外のコロニー

は，採集地にワーカーを送り込む区域(原点を中心とした半径 $r_{\max }$ の円)の面積の 3 倍を占める. したがって, 採餌探索域の面積を半径 $2 r_{\max }$ の円の面積として求めたコロニー密度は, 実際のコ ロニー密度を過小推定していると考えられる．数值例では，採餌探索域の面積を半径 $r_{\max }$ の円の 面積として推定したコロニー密度は, 本研究で提案した方法から推定されたコロニー密度に比較 的近い值を与えている(表 1).

従来の方法から得られる推定值の信頼性は, 採饂探索域内のコロニー数 $\left(N_{c}\right)$ の推定精度にも大 きく依存している. とくに, 数值例のようにワーカーが採集されなかったコロニーの数 $\left(n_{0}\right)$ の推 定值が, 全コロニー数 $N_{c}$ に対して占める割合が大きい場合には, $n_{0}$ の推定精度がコロニー密度 の推定値の信頼性に極めて大きな影響を与えていると考えられる. また，コロニー数の推定に当 たって, コロニー当たりの採集個体数がポアソン分布にしたがうとする仮定にも注意を要する. この仮定は，採餌探索域内のすべてのコロニーから等確率で採集地にワーカーが飛来することを 意味する. しかしながら，実際にはコロニーの位置が採集地から離れるにしたがって，採集地に ワーカーが飛来する確率は低くなるはずである.

今回の報告で提示した方法は，採餌探索域の面積や採餌探索域内の個体数を直接に推定するこ となくコロニー密度を推定するものであり，従来の方法が持つ上記の問題を回避している. しか しながら，提示した方法にもいくつかの問題がある. まず，今回の方法では，コロニーが平面上 に一様に分布しているものと仮定しているが，実際には営巣に適した区域にコロニーが集中して 
いる可能性がある. また，実際の適用に際しては， $\sigma^{2}$ の推定にも注意が必要である. 表 1 に示し たように, $\sigma^{2}$ の推定に際して設定する $\alpha$ の值によって, コロニー密度の推定值に 2 倍近い違い が生じることがある．保全の問題を考えるならば， $\alpha$ の值を小さめに設定し，より控えめな推定 值を得ることが無難であろう，さらに，任意の地点にあるコロニーから採集地点に個体が飛来す る確率の 2 変量正規分布による近似 (式 (1)) の妥当性についても検討が必要である. 個体がコロ 二ーから飛び立ち，ランダムな移動と訪花を繰り返して採集地点を訪れる場合は，中心極限定理 より式 (1) による近似は妥当である. しかしながら，採集地点を訪れるまでの移動・訪花回数が 少ないときは，個体の飛来確率は，式 (1)よりも急尖 (leptokurtic)になる (Wright, 1969)，以上の 問題は今後, シミュレーション実験によって仮定が満たされないときのロバスト性を評価する必 要がある.

以上のように，それぞれの方法は固有の問題を含んでいる. しかしながら，提示した方法は， 従来の方法とは異なる仮定に基づくものであり, 実際の解析に当たっては従来の方法と併用して 両者の結果を比較することで, よりコロニー密度に関して信頼性の高い情報が得られることが期 待される.

最後に, Wright $(1946,1969)$ の近傍の大きさの概念に基づいて, 提示した方法から得られた 結果の保全遺伝学的利用について考える. コロニーの有効数, すなわち無作為に抽出した 2 個 体が同一のコロニーに属する確率の逆数は, $1 / Q$ として推定できる. $1 / Q=4 \pi \sigma^{2} d$ であるから, コロニーの有効数は, 半径 $2 \sigma$ の円内に存在するコロニー数に等しい. エゾオオマルハナバチの 例では, $\alpha=0.7$ を仮定すれば $1 / Q=116.2$ であり，これは半径 $0.90 \mathrm{~km}$ の円内に存在するコロ 二ー数である. 冒頭で述べたように，集団の有効な大きさ $\left(N_{e}\right)$ はコロニー数の 1.5 倍, すなわち $N_{e}=1.5 / Q$ として推定できる. エゾオオマルハナバチの例では, $\alpha=0.7$ とすれば $N_{e}=174.3$ で ある. 個体の移動距離の制約によって生じる近親交配による近交係数の世代当たりの上昇量 $(\Delta F)$ は $\Delta F=1 / 2 N_{e}$ によって与えられるので, 約 $0.29 \%$ 程度と推定される. ただし，これらの計算は 繁殖に直接関与しないワーカーのデータによるものである点に注意を要する. 繁殖に直接関与す る生殖虫 (女王と雄)のうち女王は, 羽化後の配偶者の探索, 休眠前の越冬場所の探索および休眠 明けの営巣場所の探索を行うため, 出生場所からの移動距離はワーカーよりも大きいことが予想 される. 事実, Lepais et al. (2010) は分子遺伝マーカーを用いて, 英国の 2 種のマルハナバチ $(B$. lapidarius と B. pascuorum) では女王の移動距離はワーカーの採餌探索距離の数倍に達すると推 定している.この結果は, 実際のマルハナバチ集団ではワーカーの採餌探索距離から期待される よりも広範囲で遺伝子流動が起こっていることを示唆しており，上記の集団の有効な大きさの推 定值は，控えめな值と見なすべきであろう．マルハナバチの希少種の保全をより厳密に遺伝学的 側面から考えるには，非侵襲的サンプリング法を利用して女王についてもデータを収集する必要 がある.

\section{謝辞}

本研究は, JSPS 科研費 $17 \mathrm{H} 03953$ の助成を受けたものである. 


\section{参考文献}

Cameron, S.A., Lozier, J.D., Strange, J.P., Koch, J.B., Cordes, N., Solter LF, Griswold, T.L. (2011). Patterns of widespread decline in North American bumble bees. Proceedings of the National Academy of Sciences, 108: 662-667.

Charman, T.G., Sears, J., Green, R. E., Bourke, A. F. G. (2010). Conservation genetics, foraging distance and nest density of the scarce Great Yellow Bumblebee (Bombus distinguendus). Molecular Ecology, 19: 2661-2674.

Crozier, R.H., Pamilo,P. (1996). Evolution of Social Insect Colonies. Sex Allocation and Kin Selection. Oxford University Press.

Darvill, B., Knight, M.E., Goulson, D. (2004). Use of genetic markers to quantify bumblebee foraging range and nest density. OIKOS, 107: 471-478.

Ellis, J.S., Knight, E., Darvill, B., Goulson, D. (2006). Extremely low effective population sizes, genetic structuring and reduced genetic diversity in a threatened bumblebee species, Bombus sylvarum (Hymenoptera: Apidae). Molecular Ecology, 15: 4375-4386.

Frankham, R., Ballou, J.D., Briscoe, A.D. (2010). Introduction to Conservation Genetics. Cambridge University Press.

Goulson, D. (2010). Bumblebees: Their Behaviour and Ecology. Oxford University Press.

井上真紀, 菊池玲奈, 石川聖江, 横山 潤, 鷲谷いづみ (2007). 野付半島におけるセイヨウオオマル ハナバチの定着状況と在来マルハナバチ相. 保全生態学研究, 12: 172-175.

木村資生 (1960). 集団遺伝学概論. 培風館.

Knight, M.E., Martin, A.P., Bishop, S., Osborne, J.L., Hale, R.J., Sanderson, R.A., Goulson, D. (2005). An interspecific comparison of foraging range and nest density of four bumblebee (Bombus) species. Molecular Ecology, 14: 1811-1820.

Knight, M.E., Osborne, J.L., Sanderson, R.A., Hale, R.J., Martin, A.P., Goulson, D. (2009). Bumblebee nest density and the scale of available forage in arable landscapes. Insect Conservation and Diversity, 2: 116-124.

工藤 岳, 井本哲雄 (2012). 大雪山国立公園高山帯におけるマルハナバチ相のモニタリング調査. 保 全生態学研究, 17: 263-269.

Lepais, O., Darvill, B., O'connor, S., Osborne, J.L., Sanderson, R.A., Cussans, J., Coffe, L., Goulson, D. (2010). Estimation of bumblebee queen dispersal distance using shbship reconstruction method. Molecular Ecology, 19: 819-831.

Nagamitsu, T,, Yamagishi, H. (2009). Nest density, genetic structure, and triploid workers in exotic Bombus terrestris populations colonized Japan. Apidologie, 40: 429-440. 
中谷正彦 (1999). ノサップマルハナバチ. (釧路昆虫同好会編) 根室半島の昆虫. 釧路昆虫同好会, 129-136.

Nomura, T., Takahashi, J. (2012). Effective population size in eusocial Hymenoptera with workerproduced males. Heredity, 109: 261-268.

R Development Core Team (2016) R: A language and environment for statistical computating, R Foundation for Statistical Computing.

高橋 萌 (2016) エゾオオマルハナバチの北海道集団の集団構造に関する研究. 岐阜大学大学院応 用生物科学研究科, 修士論文.

高橋純一, 山崎和久, 光畑雅宏, Martin, S.J., 小野正人, 椿 宜高 (2010). 根室半島のマルハナバチ 相：特に北海道の希少種ノサップマルハナバチに対する外来種セイヨウオオマルハナバチの 影響について. 保全生態学研究, 15: 101-110.

Wang, J. (2004). Shibship reconstruction from genetic data with typing errors. Genetics, 166: 1963-1979.

熟谷いづみ (1998). 保全生態学からみたセイヨウオオマルハナバチの侵入問題. 日本生態学会誌, 48: 73-78.

Williams, P., Osborne, J.L. (2009). Bumblebee vulnerability and conservation world-wide. Apidologie, 40: 367-387.

Wolf, S., Moritz, R.F.A. (2008). Foraging distance in Bombus terrestris L. (Hymenoptera: Apidae). Apidologie, 39: 419-427.

Wright, S. (1946). Isolation by distance under diverse systems of mating. Genetics, 31: 39-59.

Wright, S. (1969). Evolution and the Genetics of Populations. Vol. 2. The Theory of Gene Frequencies. The University of Chicago Press.

\section{付 録}

\section{確率 $z_{i} / d$ に関する補足}

本文では, 採集地点(原点)に飛来したマルハナバチが地点 $\left(x_{i}, y_{i}\right)$ にあるコロニーから飛来した 確率を $z_{i} / d$ としたが, $z_{i} / d$ が確率としての性質を持つことと, そのために必要な条件について補 足する.

$$
z_{i} / d \text { がすべての } z_{i} \text { について }
$$

$$
z_{i} / d \leq 1
$$

であり，その全コロニーにわたる総和が

$$
\sum_{-\infty}^{\infty} z_{i} / d=1
$$

ならば， $z_{i} / d$ は確率とみなせる.

Jpn J Biomet Vol. 39, No. 1, 2018 
(A.1)の証明： $z_{i}$ は密度関数 (1) によって与えられるので, $z_{i} / d$ は原点 $\left(x_{i}, y_{i}\right)=(0,0)$ で最大值 $\left(z_{i} / d\right)_{\max }$ をとる.

$$
\left(\frac{z_{i}}{d}\right)_{\max }=\left(\frac{1}{d}\right) \frac{1}{2 \pi \sigma^{2}} \exp (0)=\frac{2}{\pi n}
$$

であるから,$n \geq 2 / \pi=0.798$ ならば, $\left(z_{i} / d\right)_{\max } \leq 1$ であり, 全コロニーに関する $z_{i}$ について (A.1)が成り立つ. $n$ は一辺が $2 \sigma$ の正方形の区画内 (面積： $4 \sigma^{2}$ )にあるコロニーの数である. 本 文中のエゾオオマルハナバチの例では $\sigma^{2}=0.2035\left(\mathrm{~km}^{2}\right)$ と推定されたので, $n$ は一辺が約 $900 \mathrm{~m}$ の正方形の区画内のコロニー数であり, コロニー密度の推定值 (表 1) $d=45.5\left(\mathrm{~km}^{-2}\right)$ を仮定する と, $n=40$ 程度と推定される. これまでに報告されてきたマルハナバチ種の採餌探索距離に基づ くと, いずれの種でも面積 $4 \sigma^{2}$ を持つ区画は一辺が数百 $\mathrm{m}$ から $1 \mathrm{~km}$ の正方形と考えられる.こ の区画内には多数のコロニーが存在すると考えられ, $n \geq 2 / \pi$ は十分に満たされているものと考 えられる.

(A.2)の証明：平面全域の全コロニーにわたる $z_{i} / d$ の総和 $\sum_{-\infty}^{\infty} z_{i} / d$ は, $1 / d$ が小さい場合(コロ ニ一密度が極端に低くない場合)には, つぎのように積分で近似できる.

$$
\sum_{-\infty}^{\infty} \frac{z_{i}}{d}=\int_{-\infty}^{\infty} \int_{-\infty}^{\infty} z d x d y=1
$$

したがって(A.2)が成り立つ.ここで, $z$ は式 (1) で与えられる密度関数である. 